\title{
Recent patent applications related to stem cells
}

\begin{tabular}{ll} 
Patent number & Description \\
\hline US 20110294218 & $\begin{array}{l}\text { A new nucleotide sequence of adeno-associated virus } \\
\text { capsid or its modified viral capsid protein (VP) 1, VP2 } \\
\text { or VP3 portion and a method of generating induced } \\
\text { pluripotent stem cells from somatic cells without per- } \\
\text { manent introduction of foreign DNA, where the stem } \\
\text { cells are transiently transduced with vectors; useful for } \\
\text { preventing and/or treating liver or systemic condition, } \\
\text { e.g., hemophilia and arthritis. }\end{array}$ \\
WO 2011146395, & $\begin{array}{l}\text { A method of transplanting mammalian cells, involving } \\
\text { introducing the mammalian cells derived from donor } \\
\text { stem cells to a recipient, and providing the recipi- } \\
\text { ent with a cocktail comprising at least two leukocyte } \\
\text { costimulatory molecule-blocking agents for a period of } \\
\text { time sufficient to allow for long-term engraftment of the } \\
\text { mammalian cells. }\end{array}$
\end{tabular}

WO 2011146902, A bi-specific fusion protein comprising a targeting

US 20110286976 domain and an activator domain; useful for preventing cell damage and promoting cell growth, motility of stem cells and differentiation of stem cells.

WO 2011146607 An isolated reprogrammed cell induced from a differentiated cell, capable of being further reprogrammed to a less differentiated state. The reprogrammed cell forms colonies with distinct morphologies and is capable of self-renewing for at least 20 passages before senescence.

US 20110287974 A method of ascertaining biosafety of an agent, involving contacting the agent with differentiating human pluripotent stem cells and analyzing a level of gene expression of several genes in the differentiating human pluripotent stem cells.

US 20110286974 A method of treating diabetes or other glucose regulation disorder comprises removing L-cells or K-cells from a donor; obtaining stem cells from a patient; culturing the L-cells or K-cells in the presence of the stem cells under conditions such that the stem cells differentiate into stem cell-derived L-cells (SCDLCs) or stem cellderived K-cells (SCDKCs), respectively; and introducing the SCDLCs or SCDKCs into the patient to cause a lowering of the patient's blood glucose level after the ingestion of food.

WO 2011145110 A novel cord blood plasma nutrient formulation for suspending stem cells for autologous and/or allogeneic transplantation and therapeutic use in treatment of degenerative diseases, where the formulation is derived from umbilical cord blood.

WO 2011143522 A method of increasing homing or engraftment of hematopoietic stem cells (HSCs) to bone marrow, involving contacting HSCs with boroproline compound or its salt or its prodrug.

KR 2011121492 A composition comprising Rho-associated protein kinase inhibitor useful for cryopreservation of human embryonic stem cell-derived cardiomyocytes.

CN 10221214 A protein comprising transactivator transmembrane pep tide and cell reprogramming related factor; useful for preparing, e.g., products for promoting cells to change to induced multipotent stem cells and for promoting cell proliferation.

\begin{tabular}{|c|c|c|c|}
\hline Assignee & Inventor & $\begin{array}{l}\text { Priority } \\
\text { application } \\
\text { date }\end{array}$ & $\begin{array}{l}\text { Publication } \\
\text { date }\end{array}$ \\
\hline $\begin{array}{l}\text { Chatterjee S, Smith L, } \\
\text { Wong K }\end{array}$ & $\begin{array}{l}\text { Chatterjee S, Smith L, } \\
\text { Wong K }\end{array}$ & $4 / 30 / 2010$ & $12 / 1 / 2011$ \\
\hline
\end{tabular}

Stanford University

Davis M, Pearl J, Wu J

$5 / 27 / 201011 / 24 / 2011$ $12 / 1 / 2011$

Davis M, Pearl J, Wu J

Merrimack

Pharmaceuticals

(Cambridge, MA, USA), Nielsen U (Cambridge, MA, USA)
Harvard College
Delabarre B, Harms B, Linggi B, Lippow SM,

Nielsen U, Onsum M, Schoeberl B, Wickham T

Blanchard J, Lam K, Rubin L
5/21/2010 11/24/2011, $11 / 24 / 2011$

$5 / 18 / 2010 \quad 11 / 24 / 2011$

Benvenisty N, Mayshar Y, 5/24/2010 11/24/2011 Development Co., Hebrew Yanuka $\mathrm{O}$

University of Jerusalem

(Jerusalem)

Imran M

Imran M

$4 / 7 / 2010 \quad 11 / 24 / 2011$

Dravida S

Akkinepally D, Dravida S

$5 / 15 / 2010 \quad 11 / 24 / 2011$

Dara Biosciences (Raleigh, NC, USA)

Didsbury JR,

$5 / 13 / 2010 \quad 11 / 17 / 2011$

Severynse-Stevens D

Seoul National University

Research and

Development Business

Foundation (Seoul)

Institute of Genetics \&

Developmental Biology,

Chinese Academy of

Sciences (Beijing)
Choi YM, Kim YY, Ku SY, Moon SY, Oh SK

Cao J, Chen B, Dai J, Xiao Z
4/30/2010 11/17/2011

5/5/2010 10/12/2011

fic Search Service. The status of each application is slightly different from country to country. For further details, contact Thomson Scientific, 1800 Diagonal Road, Source: Thomson Scientific Search Service. The status of each application is slightly different from country th 